BIBLID: 0015-1807, 48 (2021), 1 (pp. 63-82)

УДК 81'37.09:82]::1

https://doi.org/10.18485/fpregled.2021.48.1.4

Ранко Козић

Универзитет у Београду - Филолошки факултет

kozic.ranko@mts.rs

\title{
СЛИКА И МИСАО У ЈЕЗИЧКОМ ПРАСТАДИЈУМУ И ЊИХОВ ЗНАЧАЈ ЗА СТУДИЈЕ ФИЛОЛОГИЈЕ, КЬИЖЕВНОСТИ И ФИЛОЗОФИЈЕ
}

\begin{abstract}
Апстракт: Предмет ове студије је креативни потенцијал језика садржан у његовим најдубљим слојевима, до којих нас може довести једино коренско познавање речи. Креативност тог потенцијала огледа се у сликама и метафорама које у себи садрже сву снагу, љупкост и свежину којима је свој однос према свету и времену покушавала да заодене примордијална језичка свест. Највеће искушење и истовремено највеће задовољство за истраживаче представља успостављање логичких релација између слика, метафора и тропа које се развијају из корена, чиме се стварају претпоставке за усвајање језичке логике, ито није могуће постићи већ устаљеним методама изучавања језичке материје и од чега суитински зависи студиј свих хуманистичких наука. Најзначајнији закључак који би се могао извући из овог продора у семантички спектар морфема састојао би се у констатацији да нам управо сама коренска семантика и њене смеле метафоре указују на пут који води до сублимне креације у подручју кьижевности и филозофије, ито се поткрепљује навођењем паралелизама између коренских слика и метафора насталих спонтано и оних литерарних и филозофских уобличених артифицијелно и што само по себи више него речито указује на потребу темељног истраживања метафорике европске књижевности.
\end{abstract}

Кључне речи: коренска семантика, херменеутика, настава језика књижевности и филозофије у школском систему, индоевропска филологија, језичка логика, теорија превођења.

Посвећено сећаюу на академика Ивана Клајна

\section{Увод. Одјеци и сазвучја из дубине времена}

Студијско подручје чији је предмет почетни, примордијални период историје, било да се тај период означава као предисторија или праисторија или пак као рана историја, поседује, услед недостатка историјских извора, неодољиву чар мита и сву његову, понекад обесхрабрујућу, вишезначност, која је истраживачима утолико привлачнија што их ослобађа баласта клишетираних представа и што им пружа заводљиву прилику да се препусте магији и мистици „путева који се”, како би то рекао Ханс-Георг Бек (Beck) 
„губе у дубини времена." Управо ово одсуство историјских извора и неоспорних доказа релативизује готово све резултате у студијском подручју праисторије и праисторијске археологије надахнутих племенитим идеалом да се продре у устројство праисторијског космоса и менталног склопа његовог типичног представника. Једино упориште које би нам помогло да се донекле приближимо остварењу тог идеала је сама језичка материја. У њој се много уверљивије него што је то случај с траговима материјалне културе артикулишу призвуци из дубине времена, који на одвећ карактеристичан начин говоре о духовном свету и широком распону видног поља, којим је човек примордијалног периода настојао да у сликама запахнутим свежином митског времена обухвати и у систем логичких релација доведе силе које пресудно управљају његовим животом. Само се по себи разуме да је овде реч о студијском подручју индоевропске филологије у пресудној мери заснованом на класичној филологији, уз претходну напомену да ће општа разматрања овог типа изнедрити и већма опипљиву практичну корист за наставу језика, књижевности и филозофије у целокупном школском систему.

Управо те слике, иманентно присутне у самом морфему и значењима која се из њега развијају, сведоче о креативном потенцијалу језика већ у његовој најранијој фази као и о крајње рационалном односу човека поменутог периода, одвећ видљивом из његове тежње да успостави цео низ аналогија којим се у блиску везу доводе на први поглед крајње диспаратне слике и значења који извиру из истог корена. Поменути систем аналогија и логичких релација представља сам по себи добитак првог реда, зато што нам више него зорно показује механизме на којима миленијумима функционише језичка логика и без којих није могуће промишљати феномен језика као такав нити продрети у његове високе и дубоке регистре, а самим тим, како ћемо ускоро видети, ни адекватно превести захтевна дела из целог спектра хуманистичких дисциплина, са свим фаталним последицама које из тога проистичу по читаво подручје културе једног друштва, од којих је свакако најболнија она која говори о томе да при оваквим дефицитима у настави језика нису у крајњој инстанци могуће ни озбиљне универзитетске студије, о чему ће још бити речи у наредним сегментима нашег излагања.

\section{Идеал}

У којој су мери фундиране ове прелиминарне тезе, најбоље ће се видети на примерима који ће уследити. Они сами по себи представљају репрезентативан узорак, утолико што сведоче о односу човека примордијалног периода према силама за које је судбински везано његово постојање као што су климатске прилике, односно агрегатна стања, кроз која у једној врсти парадигматичне метаморфозе пролази вода као животодавни

${ }^{1}$ Das byzantinische Jahrtausend, C. H. Beck'sche Verlagsbuchhandlung, München 1994², 7. 
Ранко Козић, Слика и мисао у језичком прастадијуму и њихов значај за студије ...

елемент, увлачећи у своје семантичко поље све оно што с њом долази у непосредни контакт. О томе сведочи исто тако и цело подручје житне, зрнасте, махунасте и бобичасте флоре из које човек предисторијског космоса црпе неопходну супстанцу за одржавање живота у одвећ кратком бдењу својих чула на планети земљи.

Најпре првопоменути случај. Кореном *(s)na-, *(s)nav-, *(s)nu- и његовим проширењем у виду *(s)nabh- означава се цео циклус кружења воде у природи од почетних степена кондензације водене паре у виду лакших и тежих облака (лат. nubes; гp. nephéle), који се растварају у кишу (си. snavas), снег (енг. snow, $н$. Schnee, срn. снег) и маглу (н. Nebel), преко феномена капања течности (cu. snaimi) па све до самог запљускивања копна од набујале воде (гр. náma, narós), при чему потом у исту семантичку сферу улази све оно што се налази у непосредном контакту с водом, било да је реч о пливачу (гр. néo, néchomai, лат. nare) или броду (гp. naus, лат. navis, $с и$. navas, $\mu$. Nachen, $\phi p$. nef) или пак острву (гp. nésos) које се доживљава као копно које плута или пак о бићима која бораве у морским пространствима као што су нимфе Најаде (гp. Naiás) и Нереиде (гр. Nereís). Најсмелије слике које извиру из семантичког поља овог морфема представљају метафора дојења односно исхране као гутања снега [лат. *(s)nutrio, енг. nourish, um. nutrire, $\not p$. nourrir] због блештаво беле боје млека која на снег подсећа, као уосталом и метафора носа (л. nasus, $\phi p$. nez, $н$. Nase, енг. nose) као канала кроз који исто тако струји течност, али овог пута згуснута, наиме секрет. Видимо да су представници овог примордијалног космоса били обузети племенитом тежњом да до максимума напрегну свој поглед и прошире своје видно поље како би се све релевантне аналогије њиме могле обухватити и потом довести у систем логичких релација, чији се широк лук базира на два основна принципа: causa ex effectu и effectus e causa, наиме узрок уместо последице и последица уместо узрока, при чему се међупростор између тих полова препушта неспутаном деловању метафора, тропа и метонимија, чија употреба додатно модификује значење одређеног израза и даје му, у случају успелог захвата, карактер ненадмашне стилске чари и елеганције.

А сада пример другог животодавног елемента какава је житна, махунаста и бобичаста флора. Кореном * piș- присутном у готово свим својим модификацијама у латинском глаголу, чије је значење тући, ударати, млети и самлети и који се наводи у чак једанаест својих облика (pinso, piso, pinsěre, pisěre, pisare, pinsi, pisui, pinsum pistum, pinsìtum и pisātum), означава се цела нутритивна сфера почев од житног зрна (ссл. pšenica) као узрочника целог процеса, као уосталом и од плода осталих зрнастих биљака, пре свега махунарки (um. pisello од лат. pisum $^{2}$ ), преко воденичара (лат. pistor) и његове делатности која се

${ }^{2}$ Cf. такође фр. pois и енг. pea (грашак). 
састоји и млевењу и дробљењу зрна (лат. pisere, pinsere, pisare, гp. ptísso) и његовм претварању у брашно (ссл. рšеno), до финалне фазе, сада с руком (cpn. pesnica ${ }^{3}$ ) као инструментом делања уместо воденичног точка, наиме фазе која се састоји у пресовању и компримовању теста (um. pestare од поз. лат. pistare, као и фpp. piser), његовом претварању у хлеб (cu. pišta, pištaka) и његову укуснију верзију у виду пице (um. pizza од *pinza), иначе речи истог корена. Семантичко поље овог корена шири се и даље како би се њиме могле обухватити још две делатности од изузетног егзистенцијалног значаја као што је муљање грожђа (um. pigiare od лаm. pisum $\left.^{4}\right)$, при чему сад као инструмент делања више не фигурира рука него нога и при чему предмет самог захвата није више тврдо житно зрно него његова метафора у виду великог и сочног зрна грожђане бобе од које се добија животодавно пиће вино, а на самом крају асоцијативног низа могу се уместо људских ногу замислити и коњске које својим топотом табају пут који се управо због тога и зове писта (um. pista $\phi p$. piste). Последње проширење значења овог корена носи карактер одвећ смеле метафоре, будући да се њиме сада означава влас косе (лат. pilus, um. pelo, $\not p$. poil), која у некој далекој аналогији подсећа на влати траве, односно стабљику жита, и у крајњој инстанци на густу длаку руна које се попут жита и грожђа подвргава истом процесу компримовања, сабијања и ваљања, из чега као финални производ настаје важан одевни материјал плиш (ссл. pliš, тj. сомот), односно филц (н. Filz). На први поглед чини се да је овим семантички потенцијал корена *piṣ- до краја исцрпљен али изглед вара, пошто ће се, како ћемо одмах видети, испоставити да то ограничење важи само за материјалну, односно конкретну сферу. И доиста, поменутим кореном успоставља се у једној врсти само наизглед парадоксалне аналогије релација са светом књиге и писма, будући да се она погледу човека раних периода цивилизације, конкретно нашим далеким прецима, сама од себе наметала, с обзиром на то да их је састављање текста неодољиво подсећало на уобличавање, моделовање и својеврсно вајање теста ${ }^{6}$ (поз. лат. pistare, um. pestare), чиме се свом сили-

${ }^{3}$ Иако Petar Skok, Etimologijski rječnik hrvatskoga ili srpskoga jezika, Jugoslavenska akademija znanosti i umjetnosti, Zagreb, 1972 s. v. pesnica ову реч доводи у везу с кореном *(s)pen- ипак допушта могућност укрштања с италијанским pestare и познолатинским pistare.

${ }^{4} \mathrm{Cf}$. такође фр. piser.

${ }^{5} \mathrm{Cf}$. Ottorino Pianigiani, Vocabolario etimologico della lingua italiana. Società editrice Dante Alighieri, Albrighi 1907 s. v. pista: “... dal lat. pistus. La via che battono i cavalli nelle corse”.

${ }^{6}$ Истине ради, Max Vasmer, Russisches Etymologisches Wörterbuch, Carl Winter Universitätsverlag, Heidelberg 1955 (s. v. pismo) и Skok (1972: s. v. pismo) саму реч доводе у везу с кореном *peik- (cu. pinçati украшавати) и, између осталог, с латинским глаголом pingere (сликати), али, ако се ствар посматра с чисто фонетске стране, чини се да је веза поменуте речи с кореном * piș- мало упадљивија, што се може закључити и из одраза који потоњепоменути корен налази у санскриту, наиме pinasti, и што се метатезом гласова $a$ и $s$ добија облик *pinsati, који је већ на први поглед знатно ближи како нашем глаголу писати тако и већ наведеним латинским инфинитивима pinsere и pisare него што је то већ наведени облик pinçati од корена *peik-. Као још уверљивији доказ могао би се навести сcл. pšeno (брашно) постало од 
ном намеће паралела с платонском филозофијом, у којој се говор као такав и сама литерарна делатност, осим као јело и гозба ${ }^{7}$, доживљавају управо као скулптура, односно моделовање ${ }^{8}$, при чему треба напоменути да је готово иста аналогија присутна и у латинској речи универзалне распрострањености textus, која садржи метафору писма и говора као ткања (texo, texěre, texui, textum). Овим је пређен пут од конкретног ка апстрактном при чему се чини да би било сасвим умесно говорити о апстрактизацији конкретног, која као и поступак у обрнутом смеру, наиме конкретизација апстрактног, иначе и једно и друго заштитни знак платонизма свих периода ${ }^{9}$, представља заједно с већ поменутим принципима као што су effectus e causa, causa ex effectu, тропа, метафора и метонимија, важно начело модификације значења присутног у морфему.

Довољно је да бацимо само један летимичан поглед на цео спектар значења која се метафорички развијају из корена *piș- како бисмо утврдили размере креативног потенцијала језика, који се на најузорнији могући начин испољава у смелој метафори косе и руна као траве тела. Врхунац изненађења, које поприма карактер чудесног, састоји се у чињеници да оно што се сасвим спонтано развило из корена речи налази своју паралелу у артифицијелним настојањима литерата да створе упечатљиве слике истог, смелог

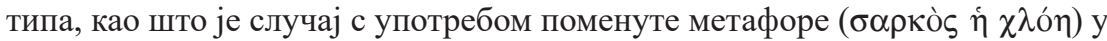
Продромовом роману ${ }^{10}$, у којем је она засветлела као мистичка лампица и

*piseno, утолико што бисмо онда имали још директнију паралелу према свету књиге и писма, будући да расквашено брашно и тесто у некој далекој аналогији подсећа на восак као подлогу за писање у дрвеним таблицама, које су као средство комуникације биле у широкој употреби током античког времена.

${ }^{7}$ Као нарочито карактеристично може се навести место из пете књиге Државе (475c) у којем се истински филозофи представљају као гурмани, а сама филозофија као јело које

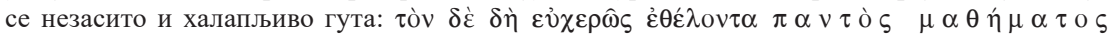

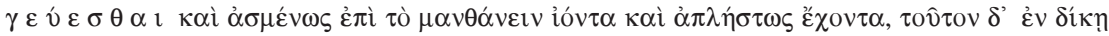

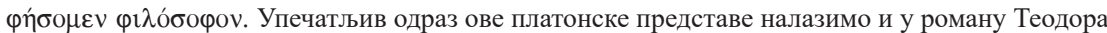

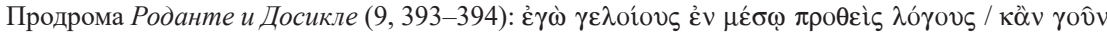

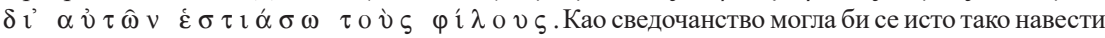
и Каликлова (Gorg. 490d) комична карактеризација Сократових говора који се увек врте око

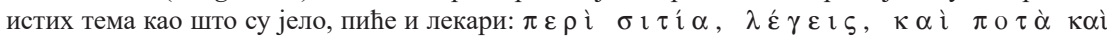

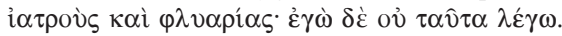

${ }^{8}$ Rp. 540c, 487e, 501g. Cf. Arist. Poët. XXIV, 1460b.

${ }^{9}$ Налазимо их чак и у неоплатонизму 18 . века, конкретно у делу марбуршког филозофа Дитриха Тидемана (Dietrich Tiedemann) чија је интерпретација Плотина и новоплатонизма (Geist der spekulativen Philosophie) извршила знатан утицај на Новалиса, о чему сведоче његове забелешке преузете из поменутог дела (das Abstracte soll versinnlicht und das Sinnliche abstract werden-Entgegengesetzte Operationen-die Eine mit der Anderen besteht und vollendet wird). Cf. Hans-Joachim Mähl, ,Novalis und Plotin”, Wissenschaftliche Buchgesellschaft, Darmstadt 1986 (Novalis: Wege der Forschung, Bd. CCXLVIII, 357-423= Jahrbuch des Freien Deutschen Hochstifts, Tübingen 1963, 139-250), 393.

${ }^{10}$ Реч је о пасажу из шесте књиге (vv. 292 - 298) у којем се с лирским надахнућем говори, између осталог, и о чемпресу младости, ружи образа и уста, бршљану увојака, љиљану

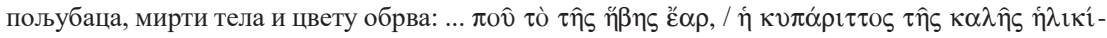

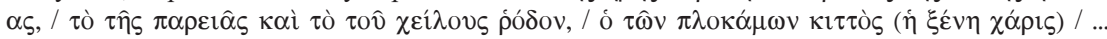


одлучујуће допринела томе да из целог дела свом силином провејава утисак највеће могуће креативности, иако је реч само о вештој адаптацији постулата платонске филозофије као, уосталом, и целокупне песничке материје у поменутом роману епохе Комнина. Нашу пажњу, када је у питању спектар значења која се органски развијају из поменутог корена, привлачи исто тако и замена улоге воденичног точка, коју преузимају делови тела какви су рука и нога, да би у завршној транслацији ту исту улогу на прилично комичан начин преузело коњско копито, које, уместо жита, грожђа и теста, меље и мрви ситне каменчиће и таба тло, како би од њега постао друм, односно писта. Да парадокс буде још већи, овај принцип замене улога делова тела, доминантан у семантичком спектру корена *piș-, постаје, кад су литерарни поступци у питању, један од најзначајнијих видова испољавања драмског ${ }^{11}$ у књижевности, о чему на најбољи могући начин сведочи и замена улога делова тела, наиме руке и језика, а реч је о захвату којим се, уз додатак чаробне митске слике, у свом Псеудологисти Лукијан из Самосате савршено послужио, како би се на ефектан и комичан начин разрачунао с противником својих књижевно-естетских начела. У управо поменутом дијалогу језик се као живо биће жали да му је силом наметнута фунција руке и да уместо за артикулацију узвишених идеја и концепата сада служи само за опсцене и перверзне радње током ноћи, да би у очајању пожелео да и њега самог, као што је то био случај са Филомелиним, неко одсече ${ }^{12}$.

Али кључна поука која се свом силином намеће из наведених примера говори о томе да нам без поседовања ових базичних знања остаје ускраћена

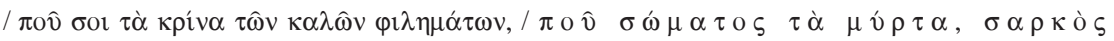

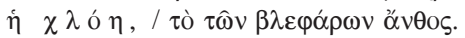

${ }^{11}$ Појмовни спектар термина drama обухвата сваку врсту транслација и преноса, какав је пренос на небо стања на земљи и сликање богова са свим људским слабостима, као што је то случај у Лукијановом дијалогу Iuppiter tragoedus (Зевс трагични глумаи), у којем се у комичним цртама слика палата богова на небу и насушна потреба њених становника за земаљском материјом попут троношца, мириса и мантичких извора. Поменутим спектром обухваћена је исто тако и транслација у супротном смеру, као што је пренос на земљу прилика на небу у настојању да се у људском обличју што је делотворније могуће игра улога бога на земљи, као што су, уосталом, истим спектром обухваћене и све врсте одраза и печата, које све ствари и бића остављају једни на друге, што за крајњу последицу има управо то да у једној врсти чудесне метаморфозе све увек подсећа на нешто друго, чиме свака ствар и свако биће поприма карактеристике симбола, онако као што је то случај са фигуром код Лукијана експлицитно означеном као симбол, управо стога што су се на њој до границе нераспознатљивости стопиле црте мушких и женских ликова - Диониса, Деукалиона и Семирамиде (Syr. 33): ‘̉v $\mu \dot{\varepsilon} \sigma \omega \delta \dot{\varepsilon}$

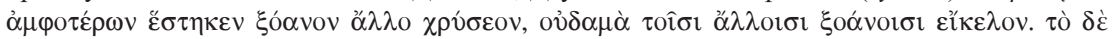

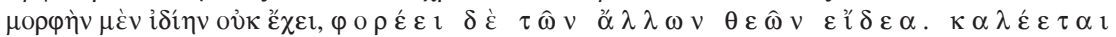

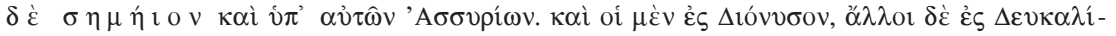

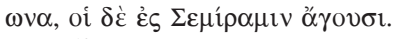

${ }^{12}$ Pseudol., 25: $\kappa \alpha \grave{\imath} \quad \dot{\alpha} v \tau \grave{i} \quad \gamma \lambda \dot{\omega} \tau \tau \eta \varsigma$ ö $\sigma \alpha \quad \kappa \alpha \grave{i} \quad \chi \varepsilon \imath \rho \grave{i} \quad \chi \rho \hat{\eta} \sigma \theta \alpha \imath$

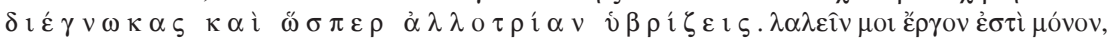

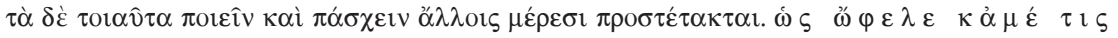

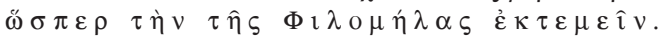


заводљива и, пре свега, креативна игра, за коју се сам од себе нуди енормни плазматички и протејски потенцијал морфема, потенцијал који сам по себи представља најбољи протрептик и паренезу за продубљне студије књижевности и филозофије. Могло би се рећи да без ових знања феномен језика подсећа на мирну површину реке која ничим не одаје утисак да у најдубљим деловима њеног корита теку моћне подводне струје, чији динамизам стоји у оштром контрасту према статици и непомичности саме површине. На ову кључну поуку органски се надовезује завршна поента која гласи да су смеле метафоре укорењене у бићу језика и да пут до сублимне креације у подручју књижевности води преко њих, управо онако како се поменутим стилским средством узорно за сва времена користио сам Платон, чији се стил у Горгији у једној врсти јетке ироније, упућене од Каликла његовој масци Сократу, карактерише управо као пеапіеиеsthai ${ }^{13}$, другим речима као giovanile baldanza, тј. као младалачка смелост и дрскост и доводи у непосредну везу с успешним говорним наступом пред окупљеном гомилом света, не нужно судског карактера, тако да се као коначан резултат ове Каликлове карактеризације Сократовог, односно Платоновог, стила искристалисао спој крајње неспојивих и диспаратних елемената као што су детињаста аргументација и ефектна форма политичког говора у знаку младалачке смелости и дрскости, што је само по себи у виду крилатице реторика за дечаке $и$ омладину могло бити с одушевљењем прихваћено у реторским школама и дати повод за системско конципирање једне нове реторике и једног новог жанра, какав је антички роман ${ }^{14}$, на платонским основама, онако како оне, заоденуте у чаробне боје поезије, долазе до изражаја, пре свега, у Горгији, Федру и Симпосиону.

О снази и ефектности ових слика које извиру из корена можда најбоље

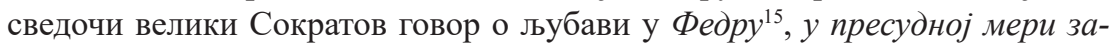
снован на представи крилате кочије ${ }^{16}$, органски израсле из юеговог играња

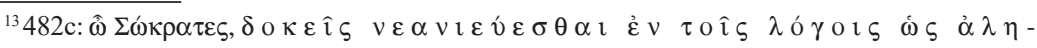

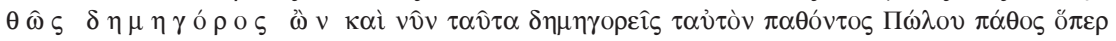

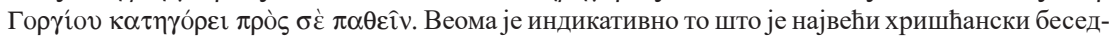
ник Григорије из Назијанза neanieuesthai доживљавао као сигнатуру свог стила, што више него речито говори о утицају нове реторике у Горгији на потоње епохе. Cf. Eduard Norden, Die antike Kunstprosa vom VI. Jahrhundert v. Chr. bis in die Zeit der Renaissance, Teubner, Leipzig1915³, 567.

${ }^{14}$ И у случају истраживања настанка и поетике античког романа као жанра [cf. нашу студију $\Delta \rho \hat{\alpha} \mu \alpha, \pi \lambda \alpha \dot{\sigma} \sigma \alpha \alpha$ e $\mu \hat{v} \theta$ os nei romanzi di Achille Tazio e del Macrembolita e i fondamenti filosofici del genere, Classica et Christiana 11 (2016), 157] било је потребно да се до крајње мере напрегне поглед како би се могао обухватити цео семантички спектар термина drama који и сам, у складу с поменутим законитостима, запрема широк лук од праузрока до крајње последице - од митске теме и њене концептуалистичке обраде у сценарију до самог краја драмске представе која је сва у знаку преображаја, перипетија, изненадних обрта, метаморфоза и метаморфотичких телесних и душевних стања. Тек после дешифровања семантичког спектра поменутог термина било је могуће приближити се решењу енигме настанка романа као жанра.

${ }^{15} 244 \mathrm{a}-257 \mathrm{~b}$.

${ }^{16} 246 \mathrm{a}-249 \mathrm{~b}$. 
семантичким спектром појма Eros, који он креативно тумачи као поједностављење почетног облика * pteros $^{17}$, чиме се поменути персонификовани појам, односно властито име ћудљивог божанства љубави, доводи у везу c peчjy pterón („крило”), како би се на упечатљив начин представила свака врста успона везаног за еros ${ }^{18}$ и с њим повезаног лета, који се, уколико поприми свој филозофско-мистички вид, завршава у непрестаном отклону од свега земаљског и материјалног у наднебеској сфери, управо у наднебеској долини (hyperouránion). О снази смелих метафора, које подсећају на оне које се развијају из корена, више од било чега другог говори чувени пасаж из шесте књиге Државе у којем Сократ посеже за поменутим стилским средством као једино делотворним у свом покушају да скептични и ненаклоњени му аудиторијум увери у то ко је и како изгледа истински филозоф. Тако је, кад већ ништа нису помогли ни дедукција ни логички аргументи, настала чаробна представа чудесне, ненадмашне лепоте с одвећ препознатљивим карактеристикама младалачке метафоре, у којој се истински филозоф поистовећује с особом која долази право ниоткуда, управо с крајње маргине друштва, особом која увек налази заштиту и заклон иза зида од прашине коју подиже олујни зимски вихор ${ }^{19}$, што само по себи више него речито говори о значају игре коренским и њима сродним песничким сликама за сваки вид бављења литерарном и филозофском делатношћу, а тиме посредно и о значају познавања морфема, његових метафора и његових тропа. Као својеврсни симбол овог креативног играња језичком материјом могла би се исто тако

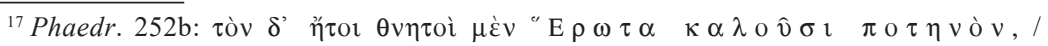

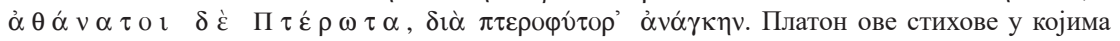
се јавља поменута етимологија доводи у везу с тајним песмама хомерида, при чему је овде по свој прилици реч о Платоновој инвенцији кад је у питању како њихова атрибуција тако и њихов садржај. Веома је индикативно да се ова једина нама сачувана етимологија Еросовог имена доводи у експлицитну везу с језиком богова, чиме се и само настојање да се продрре у подручје коренске семантике уздиже до сублимних висина. За атрибуцију стихова cf. Giovani Reale, Platone. Fedro, intoduzione, traduzione, note e apparati, Bompiani, Milano 2000 (Bompiani testi a fronte 16), 230. n. 119.

${ }^{18}$ Веома је индикативно то што најпознатији речници класичног грецитета као што су Бајијев (Bailly: 1950), Монтанаријев (Montanari: 2013³), Лидл-Скотов (Liddell-Scott: 1843) и Пасовљев (Passow: 1841) не доносе никакву етимологију уз овај важан појам.

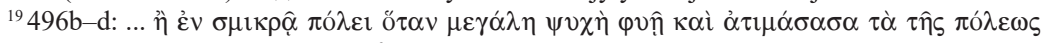

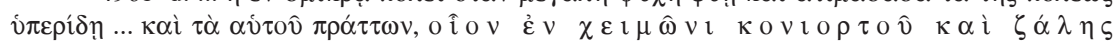

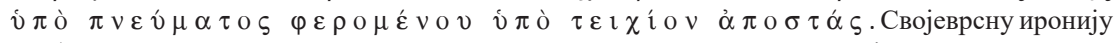
судбине представља чињеница да ову прегнантну, сликовиту, упечатљиву, језгровиту и надасве искуством потврђену дефиницију филозофа данас више нико не узима за озбиљно и поред упозоравајуће констатације злокобног призвука из истоименог дела, у којој је реч о томе да људске заједнице неће уопште имати прилику да предахну од плиме зла, уколико истински филозофи не преузму кормило државе или уколико пак сами владаоци не почну да се на достојан начин баве филозофијом. Рекло би се да је данас на снази сасвим супротан идеал, чије оличење представља добро етаблирани филозоф академског и салонског типа, чија се учења могу идеално подвести под оно што се код Ничеа (Nietzsche) крајње комично означава као scienza gaia, односно fröhliche Wissenschaft. 
Ранко Козић, Слика и мисао у језичком прастадијуму и њихов значај за студије ...

навести и Каликлова карактеризација Сократових стилских и мисаоних проседеа у Горгији, у којој је сам Сократ поистовећен с балавим дететом које се, док љупко тепа и замуцкује, игра својих омиљених игара ${ }^{20}$, што, без обзира на своју комичну ноту, садржи у себи сублимни вид истине, тим пре што се ова парадоксална слика свом силином сама од себе препоручивала да поприми амблемски карактер целокупне платонске филозофије, утолико што је сам Сократ представљен како у свом бићу и деловању сједињује опречне животне доби, какве су дечаштво и старост, и опречне менталитете, какви су они везани за необуздану детињу играрију и свештени мир зреле старачке доби ${ }^{21}$. У једној врсти прелиминарног зачључка можемо рећи да кључни концепти платонске филозофије израстају из игре коренским сликама и семантичким спектром одређеног појма, што значи да се и ми сами, да бисмо још уопште били у стању да разумемо дело највећег филозофа Запада, морамо подвргнути додатном напору, који би подразумевао продор у језгро морфема и његове магичне слике.

\section{Протрептик за један нови заокрет у студијском подручју језика и књижевности}

О потреби да такав идеал нађе своју широку примену у пракси, чак и када је савремена књижевност у питању, речитије од било чега другог говоре и ставови ауторитета какав је Томас Стернс Елиот (Thomas Stearns Eliot), чије је дело у пресудној мери обележило енглеску књижевност целог двадесетог века. Поменути ставови, саопштени у његовом чувеном есеју What is a Classic? ${ }^{22}$, препоручују се сами од себе из још једног разлога за улогу лакмус папира и катализатора наших изнесених теза, утолико што из њих провејава утисак протрептика и паренезе платонског типа за један суштински заокрет у студијском подручју књижевности и језика. Латински и грчки представљају према аутору „,крвоток европске књижевности ${ }^{23}$, ,,опште класично мерило за све изузетне домете у књижевности ${ }^{24 ”, ~ „ з а ј е д н и ч к о ~}$ наслеђе у мишљењу и осећању које само по себи једино може да гарантује међусобно разумевање припадника појединачних европских нација и јези-

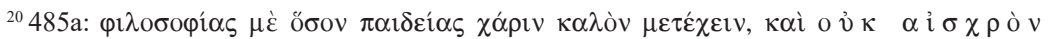

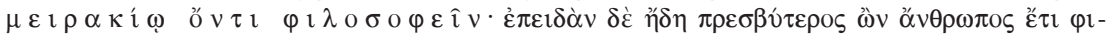

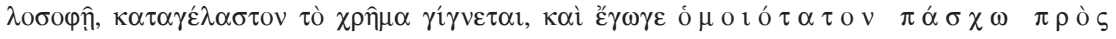

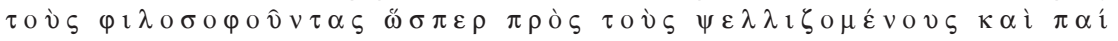
$\zeta \circ v \tau \alpha \zeta$.

${ }^{21}$ Ernst Robert Curtius (Europäische Literatur und lateinisches Mittelalter, Francke Verlag, Bern $\left.1961^{3}\right)$ није успео да у потпоглављу Knabe und Greis (109 - 115) целине насловљене Topik објасни порекло овог топоса у средњовековној књижевности на латинском језику.

${ }^{22}$ Selected Prose, edited with an introduction by Frank Kermode, Farrar, Straus and Giroux Publishers, New York 1975.

${ }^{23} \mathrm{Op}$. cit., 130: ,... blood-stream of European literature - not as two systems of circulation, but one ..."

${ }^{24} \mathrm{Ibid}:$, ... common measure of excellence in literature ..." 
ка" 25 , чиме се у не безначајној мери потврђује наше постулиране тезе. Није нимало тешко из ових Елиотових премиса извући закључак који се састоји у чињеници да је узорна рецепција античког наслеђа могућа само изнутра, тј. на језику оригинала и да поменуто наслеђе представља образовно добро стратешког - а могло би се слободно рећи и геостратешког - значаја, утолико што се оно указује као готово једина сила која је у стању да осигура потребан степен међусобног разумевања унутар широке породице европских нација, култура и језика. Истини за вољу, треба рећи да је у поменутим Елиотовим премисама присутан и један спорни детаљ, који говори о томе да је могућа рецепција важнијег дела општеевропског цивилизацијског наслеђа, какво је грчко, посредним путем преко његовог одраза у римској књижевности ${ }^{26}$, што само по себи представља последицу скучене перспективе коју му је пружало познавање само једног класичног језика и само једне класичне књижевности.

Ако је, према Елиоту, познавање античких књижевности изнутра од велике важности за сваки вид креативног бављења литерарном делатношћу, сасвим логично се намеће питање од каквог ли су тек значаја поменута знања за научно фундиране студије књижевности и поуздано естетско-поетолошко вредновање литерарних остварења насталих током дугих периода књижевне историје. Одговор на ово кључно питање стоји нам већ на дохват руке, а реч је о Ернсту Роберу Курцијусу и његовој већ поменутој славној синтези Europäische Literatur und lateinisches Mittelalter и упозоравајућој констатацији садржаној у њој која говори о томе да целокупну европску књижевност све до средине деветнаестог века, тј. до почетка индустријске револуције, није уопште могуће разумети без познавања барем једне античке књижевности, тј. римске, на језику оригинала, што би само по себи значило да би представници студијских подручја каква су романистика, германистика или пак англистика, требало да крену у школу старе филологије, што, по њему, представља захтев који би данас мало ко разуман био спреман да испостави ${ }^{27}$. Али алтернатива томе готово да и не постоји, будући да су поменута студијска подручја због недостатка дуге традиције непрестано изложена модама и странпутицама које са собом носи дух времена. Тако се ствара изобличена представа о феномену, која сама од себе производи вакуум у студијском подручју, утолико што конципирање и моделовање самог сту-

${ }^{25} \mathrm{Ibid}:$, ,... common heritage of thought and feeling in those two languages, for the understanding of which, no European people is in any position of advantage over any other ..."

${ }^{26}$ Ibid.: , ... for it is through Rome that our parentage in Greece must be traced ..."

${ }^{27}$ Op. cit., 386: „Germanistik, Romanistik, Anglistik entbehren alter Tradition. Sie fallen darum den Moden und Irrungen des Zeitgeistes leicht zum Opfer. Nur wenn sie sich entschlössen, in die Schule der alten Philologie zu gehen, könnte sich das bessern. Aber dafür müßte man Griechisch und Latein lernen - eine Zumutung, die kein Verständiger auch nur zu äußern wagen wird. Die Gründer der neueren Philologie hatten freilich die Schulung der alten Sprachen noch empfangen. Sie schufen eine Tradition strenger Forschung. Es mag wirkungslos sein, aber es ist Verpflichtung, dies Vermächtnis der großen Lehrer zu verteidigen." 
Ранко Козић, Слика и мисао у језичком прастадијуму и њихов значај за студије ...

дијског подручја према ћудљивости моде испражњава из њега сваки базичан садржај и сваку фундаменталну материју, чиме се ствара слободан простор да се на њихово место убаци све што је сувишно и непотребно и као такво једино способно да покреће све саме нове циклусе лутања и странпутица као, уосталом, и бесконачног рециклирања студијске материје у знаку једног већма негативног и забрињавајућег тренда.

Овај вакуум попримио је на овом нашем подручју геостратешку димензију, утолико што су пре скоро читавих седамдесет и пет година студијска подручја од изузетног значаја за целу сферу културе и духовну надгрању једног друштва, каква су она чији је предмет језичка, књижевна и филозофска материја, декретима идеолошке, комунистичке педагогије испражњена од свог базичног садржаја и отворена за све врсте експеримената, чиме је на крајње фаталан начин створено плодно тле да се она додатно отворе и за примену одредаба једне друге, исто тако погубне, идеологије каква је она банкарска и олигархијска, како би се под бенигним геслом глобализације ${ }^{28}$ у потпуности девастирао образовни систем нације и уништила њена елита, што је истински циљ одредаба Болоњске декларације конципиране управо на Њујоршкој берзи ${ }^{29}$. На овим чињеницама као на једној врсти тамне позадине показаће се у свој својој упечатљивости тренутно стање у којем се налази подручје истинске филологије у нашој средини, подручје од којег пресудно зависи прогрес у целом спектру хуманистичких дисциплина.

\section{Дефицити у студијском подручју језика и књижевности и тренутно стање наше филолошке инфраструктуре}

Будући да сам појам филолошке инфраструктуре није толико одомаћен у нашој стручној јавности, чини се да је потребно да на овом месту додатно прецизирамо и појаснимо шта под тим подразумевамо, и поред тога што је пажљивом читаоцу такорећи већ на први поглед јасно о чему је реч, при чему се надамо да ће поменути феномен тако наићи на опште прихватање, утолико пре што је реч о појавном облику од стратешког значаја за цело подручје културе једне нације. Под појмом филолошке инфраструктуре ми, наиме, подразумевамо три међусобно уско испреплетена подручја каква су лексикографија, публицистика, пре свега онај њен огранак чији је предмет објављивање кључних текстова европске и светске цивилизације у адекватним студијским издањима, као, уосталом, и преводилаштво схваћено у

${ }^{28}$ Michel Chossudovsky, The Globalization of Poverty and the New World Order, Centre for Research on Globalization, Montreal 2003.

29 Заинтересовани за међусобно испреплетене феномене као што су глобализација, сиромаштво и образовање могу употпунити своја знања свакодневним читањем експертских анализа на научним сајтовима из области геостратегије као што су Global Research, Strategic Culture Foundation, New Eastern Outlook, Twenty First Century Wire, Silent Crow News, World Socialist Web Site, Vineyard of the Saker и Réseau Voltaire. 
свом најширем виду. Редослед наведених подручја дат је према њиховом значају, што у овом случају значи да није могуће учинити ни најмањи могући помак у унапређењу нивоа универзитетских студија, а самим тим ни забележити помена вредан напредак у подручју културе једног друштва, уколико се сама лексикографска област не налази у стању готово потпуне довршености и перфекције. Какво је тренутно стање наше лексикографије а самим тим и филолошке инфраструктуре, већ сама по себи наговештава чињеница да ми ни данас не поседујемо лексикографски завод, а реч је о хроничном дефициту који датира још од далеке 1945. године, наиме од тренутка када су у геостратешком вакууму почеле да се на нашем подручју етаблирају идеолошка држава и њена верна служавка идеолошка педагогија. О поменутом дефициту још речитије говори чињеница да ми ни данас, ако се само изузме лексикографско ремек-дело Ивана Клајна ${ }^{30}$, уопште не поседујемо употребљиве речнике ни класичних ${ }^{31}$ ни светских језика, без којих уопште није замислива суштинска рецепција поменутог општеевропског цивилизацијског наслеђа. Кад кажемо употребљиве речнике ми пре свега мислимо на такве продукте лексикографије у којима су одреднице, односно леме, обрађене на савршено систематичан и прегледан начин, што другим речима значи да се семантички спектар одређеног појма прецизно рашчлањује и тако приказује да се његова значења, пропраћена одвећ илустративним примерима, логички и, рекло би се, органски развијају једна из других ${ }^{32}$.

Пажљив читалац могао би се сад у чуду запитати у какву се ближу везу све ово може довести с тезама изнесеним у уводним параграфима нашег излагања, у којима се у општим цртама говори о значају познавања морфема за студије свих хуманистичких дисциплина. Парадокс се састоји у чињеници да нам, уколико је реч о захтевним текстовима из области књижевне и филозофске области, ни најпрегледнији ни - из формалног и

${ }^{30}$ Italijansko-srpski rečnik, Nolit, Beograd, 1996. Треба исто тако указати на чињеницу да, кад је овај наш бивши заједнички простор у питању, још само два остварења хрватске лексикографије могу проћи најстрожу стручну проверу, а реч је о Деановићевом и Јернејевом италијанско-хрватском (Deanović - Jernej : 1973) и, пре свега, о хрватско-немачком речнику (Jakić - Hurm: 1987).

${ }^{31}$ Као куриозитет могао би се навести податак да ми ни данас не поседујемо било какав речник класичног грчког, а о каквом је вакууму реч, најбоље сведочи чињеница да је у питању језик најзначајније књижевности света, ако ни због чега другог, а оно због импозантног континуитета који увелико надмашује цела два миленијума.

${ }^{32}$ Последице неиспуњења ове фундаменталне претпоставке изузетно су фаталне, утолико што, без обзира на дужину учења неког страног језика, чак и када би оно - хиперболички речено - обухватало цео један интервал од стотину година, не би дошло ни до каквих суштинских помака у асимилацији језичке материје, а да о оној књижевној и не говоримо. Данас се на сасвим парадоксалан начин потенцира значај такозване педагошке дидактике у настави језика на нашим универзитетима у наивном уверењу њених креатора да би она могла да отклони темељни дефицит какав је одсудство помена вредне лексикографије у једној средини. 
суштинског аспекта - најсавршенији речници не могу бити од одлучујуће помоћи, уколико не владамо базичним принципима коренске семантике услед чије се игре и интеракције пресудно модификује значење речи, управо онако како је то, надамо се, уверљиво представљено у поменутим параграфима, из чега се свом силином намеће закључак да је услед изостанка поменутих фундаменталних претпоставки вероватноћа грешке у преводу прилично велика и да је свака таква грешка за тумача и читалачку јавност одвећ фатална. Другим речима, да би се постигла довршена интерпретација захтевних текстова и садржаја потребно је да се задовоље два суштинска услова као што су постојање савршеног речника и познавање принципа који детерминишу коренску семантику, утолико што је илузорно очекивати да се чак и у најсавршенијем могућем речнику могу наћи регистрована сва значења одређеног појма, а поготово оно које је пресудно детерминисано самим контекстом. Ова празнина могла би се делимично отклонити тако што би приликом израде довршених и поузданих речника савремених, пре свега, светских језика - требало увести новину која би се састојала у томе да се у скраћеници назначи принцип модификације значења одређеног појма, било да је реч о метафори, тропи, метонимији, последици уместо узрока и узроку уместо последице или пак о неким сличним далеким и на први поглед несхватљивим транслацијама. Ово тим пре што су језици великих култура наследни феномени ${ }^{33}$ који органски израстају из свог класичног претходника и самим тим преузимају највећи део његовог лексичког фонда с његовим латентно присутним првобитним семантичким набојем, што по правилу представља тежак проблем преводиоцима када су тим набојем прожета апстракта - највиши и најузбудљивији регистар једног језика. Само се по себи разуме да студенти класичне филологије имају осетну предност над својим колегама посвећеним студију модерних филологија, утолико што им је чак и за елементарно сналажење на текстовима из класичног грецитета и латинитета потребно познавање ових принципа на солидној основи.

На проблематично стање у подручју лексикографије суштински се наслања исто такво стање кад су у питању студијска, односно научна, издања кључних текстова европске књижевности и филозофије, од чије адекватне рецепције у пресудној мери зависи формирање елите једне

${ }^{33} \mathrm{O}$ дефицитима у лексикографској области на парадигматичан начин говоре запажања ауторитета какав је Ханс-Георг Бек („Das literarische Schaffen der Byzantiner, Wege zu seinem Verständnis”. Österreich. Akad. d. Wiss., phil.-hist. Kl., Sitzungsberichte, 294 B., 4. Abhandl. Wien 1974, 17) о речницима византијског грецитета: „Man könnte sehr primitiv mit dem Fehlen eines ausreichendes Wörterbuches der byzantinischen Gräzität beginnen. Das scheint absurd, wenn man von sklavischer Nachahmung der antiken Sprache hört. Doch das intrigante Problem ist tatsächlich vorhanden: auch die klassiche Sprache macht trotz allem konservierenden Bemühen ihrer Liebhaber eine latente Entwicklung durch.“ 
нације ${ }^{34}$. C обзиром на пресек стања у лексикографији илузорно би било очекивати присуство таквих подухвата у нашем научном издаваштву. Како би се избегла свака врста забуне у погледу садржаја наведеног појма опет се указује потреба за додатним појашњењем, које се суштински заснива на већ изнетим премисама у уводним сегментима излагања. Имајући у виду чињеницу да је сваки превод у мањој или већој мери споран, као неодложна намеће се потреба да се поменути кључни текстови публикују у двојезичном издању, у којем би у једној врсти јукстапозиције бити сучељени текст извора и текст превода, који би и сам био пропраћен опсежним коментарима у белешкама. Оваква издања, за којима се из наведених разлога у нашој средини осећа насушна потреба већ више од седам деценија, сама по себи представљају најбољи катализатор стања у науци и култури једног друштва и њихова ће појава представљати прву опипљиву индицију да се стање у академској области коначно променило набоље. О озбиљности стања у преводилачкој делатности, кад су у питању научне монографије, говори и лично искуство овог аутора које се може сажети у констатацији да нити један превод из поменутог домена не може проћи озбиљну стручну проверу, утолико пре што се на крају испоставило да чак ни оно, за шта се чинило да представља солидну интерпретацију изворног текста, а реч je, наиме, о славној синтези Историја Византије Георгија Острогорског ${ }^{35}$, представља само вид мање-више успешног препричавања ${ }^{36}$ оригиналног текста. Када се све ово има у виду није тешко претпоставити како би та провера изгледала када би се под лупом нашли преводи чисто литерарних, књижевних текстова.

\section{Једна већма фундирана филологија и задаци који пред њом стоје. Закључно разматрање}

Из уводних сегмената нашег излагања већ се могло наслутити колико се праваца и видика отвара истраживачу, кога покреће племенити нагон да продре у само језгро морфема, како би се нашао у прилици да сагледа сав његов ослобођени херменеутички потенцијал који је сам по себи једино у стању да гарантује успон ка све вишим нивоима спознаје. Из таквог успона произилазе и узвишени задаци које је, на примеру тропа и метафора које се развијају из корена арапских речи, епиграматски и, могло би се рећи, узорно за сва времена формулисао Гете (Goethe) у Белешкама уз Диван (Noten und

${ }^{34} \mathrm{O}$ улози филологије у формирању модерне европске државе на научној основи у ренесансној Италији cf. Karl Pfeiffer, History of Classical Scholarship 1300-1850, Clarendon Press, Oxford, 1976, 47.

${ }^{35}$ Georg Ostrogorsky, Geschichte des byzantinischen Staates, C. H. Beck'sche Verlagsbuchhandlung, München, 1940 (Handbuch der Altertumswissenschaft Band XII, 1, 2).

${ }^{36}$ Георгије Острогорски, Историја Византије, Српска књижевна задруга, Београд, 1959. 
Ранко Козић, Слика и мисао у језичком прастадијуму и њихов значај за студије ...

Abhandlungen zum besseren Verständnis des West-östlichen Divans), тачније у рубрици Праелементи орјенталне поезије (Orientalischer Poesie Urelemente):

In der arabischen Sprache wird man wenig Stamm- und Wurzelworte finden, die, wo nicht unmittelbar, doch mittels geringer An- und Umbildung sich nicht auf Kamel, Pferd und Schaf bezögen ... Wer nun also, von den ersten notwendigen Ur-Tropen ausgehend, die freieren und kühneren bezeichnete, bis er endlich zu den gewagtesten, willkürlichsten, ja zuletzt ungeschickten, konventionellen und abgeschmackten gelangte, der hätte sich von den Hauptmomenten der orientalischen Dichtkunst eine freie Übersicht verschafft ${ }^{37}$.

Ово само по себи неодољиво подсећа на платонску игру коренским сликама и младалачким метафорама које се из њих развијају, управо онако како смо то већ могли видети у уводним сегментима нашег излагања. По свој прилици овде је реч о Гетеовом претварању и прикривању истинског извора ових запажања, која се с ваљаним разлозима могу довести у везу с његовом лектиром Платона, утолико пре што је у истом контексту одвећ уочљива његова зависност од једног другог античког извора, какво је учење о стилским фигурама садржано у делу Rhetorica ad Herennium анонимног римског аутора ${ }^{38}$, у којем се управо као и у поменутој рубрици, у којој је реч о праелементима поезије ${ }^{39}$, у једној врсти протрептика заговара стилски поступак којим се у однос веома блиске аналогије доводе чак и најудаљенији могући феномени.

Поменуте задатке једино је могао уочити истраживач којег је, као уосталом и самог Гетеа, красио универзално-историјски поглед и тежња да „методолошки тако слабо засновану науку о књижевности” утемељи на чврстим основама, што је за последицу имало управо то да су у његовим чисто књижевним студијама на видело изашле најлепше стране саме филологије. Реч је поново о Ернсту Роберту Курцијусу и његовом покушају да у поменутој синтези укаже на значај истраживања метафорике за свако делотворно и суштинско проучавање европске књижевности. Управо по-

${ }^{37}$ Текст оригинала код Curtius-a (1961: 306). Превод Јосипа Бабића (Курцијус 1996: 495): „У арапском се може наћи мали број коренских речи које се, ако не непосредно, а оно пак уз ситне додатке и преиначења, не би односиле на камилу, коња и овцу ... Онај ко би, полазећи од првих, основних пра-тропа и пра-метафора, бележио оне слободније и смелије док коначно не би дошао до најсмелијих и најсамовољнијих, стекао би суверен преглед кључних момената и етапа у развоју поезије."

${ }^{38}$ 4, 47, 61 (similitudo): sed inuentio similium facilis erit si uis sibi omnes res, animantes et inanimas, mutas et eloquentes, feras et mansuetas, artificio, casu, natura conparatas, usitatas atque inusitatas, frequenter ponere ante oculos poterit.

${ }^{39}$,Schreitet man nun so fort und beachtet alles übrige Sichtbare: Berg und Wüste, Felsen und Ebene, Bäume, Kräuter, Blumen, Fluß und Meer und das vielgestirnte Firmament, so findet man, daß dem Orientalen bei allem alles einfällt, so daß er, übers Kreuz das Fernste zu verknüpfen gewohnt ... Widersprechendes auseinander herzuleiten kein Bedenken trägt.” Текст код Curtius-a (1961: 307). 
главље посвећено метафорици, иако недовршено и у форми скице ${ }^{40}$, било је погодно и отворено за даље допуне и надградње, за којима се, а да притом њих није било ни на далеком видику, већ више од пуних шест деценија осећала насушна потреба, чиме се накнадно више него уверљиво потврдила исправност његовог већ поменутог суда о ,методолошки тако слабо заснованој науци о књижевности ${ }^{41}$ ". С обзиром на то да осећамо потребу да бранимо завет великог истраживача користимо прилику да овде дамо свој више него скромни допринос проблематици проучавања метафорике европске књижевности у виду једног начелног предлога који органски произилази из уводних сегмената нашег излагања. Долазимо у искушење да поверујемо да су у овом грандиозном подухвату могуће пречице, утолико што би се прва прелиминарна фаза истраживања, онако како је то демонстрирано у уводним сегментима излагања, могла ограничити на материјал који доноси лексика, било да је реч о обимним стандардним или етимолошким речницима или пак тесаурусима класичног и не само класичног грецитета и латинитета, при чему би од велике помоћи свакако био и компаративни материјал садржан пре свега у речницима романских језика и при чему се чини да уопште не би била мала вероватноћа да ћемо, као у случају траве тела и заштитног зида од прашине коју подиже олујни зимски вихор, открити и друге, мирисном росом поезије запахнуте метафоре.

\section{ЛИТЕРАТУРА}

Beck, Hans-Georg, „Das literarische Schaffen der Byzantiner, Wege zu seinem Verständnis", Wien, Österreich. Akad. d. Wiss., phil.-hist. Kl., Sitzungsberichte, 294 B., 4. Abhandl. 1974.

Beck, Hans-Georg, Das byzantinische Jahrtausend, München, C. H. Beck'sche Verlagsbuchhandlung, $1994^{2}$.

Chossudovsky, Michel, The Globalization of Poverty and the New World Order. Montreal, Centre for Research on Globalization, 2003.

Chossudovsky, Michel, The Globalization of War. America's "Long War" against Humanity, Montreal, Centre for Research on Globalization, 2015.

Curtius, Ernst Robert, Europäische Literatur und lateinisches Mittelalter, Bern, Francke Verlag, $1961^{3}$.

Kozić, Ranko, $\Delta \rho \hat{\alpha} \mu \alpha, \pi \lambda \alpha ́ \sigma \mu \alpha$ e $\mu \hat{v} \theta$ os nei romanzi di Achille Tazio e del Macrembolita e i fondamenti filosofici del genere, Classica et Christiana 11 (2016)

${ }^{40} 138-154$.

${ }^{41}$ Наду да ће доћи до толико жељеног пробоја у истраживању метафорике побудила је релативно скорашња појава речника филозофске метафорике (Ralf Konersmann, Wörterbuch der philosophischen Metaphern, Wissenschaftliche Buchgesellschaft, Darmstadt $2011^{3}$. 
Mähl, Hans-Joachim, „Novalis und Plotin”, Darmstadt, Wissenschaftliche Buchgesellschaft, 1986 (Novalis: Wege der Forschung, Bd. CCXLVIII, 357-423 = Jahrbuch des Freien Deutschen Hochstifts, Tübingen 1963, 139-250).

Norden, Eduard, Die antike Kunstprosa vom VI. Jahrhundert v. Chr. bis in die Zeit der Renaissance, Leipzig, Teubner, $1915^{3}$.

Ostrogorsky, Georg, Geschichte des byzantinischen Staates, München, C. H. Beck'sche Verlagsbuchhandlung, 1940 (Handbuch der Altertumswissenschaft Band XII, 1, 2).

Острогорски, Георгије, Историја Византије, Београд, Српска књижевна задруга, 1959.

Pfeiffer, Karl, History of Classical Scholarship 1300-1850, Oxford, Clarendon Press, 1976.

\section{ИЗВОРИ}

Anonymus, Rhetorica ad Herennium (Ad C. Herennium de ratione dicendi) - translated by Harry Caplan, Cambridge Massachusetts, Harvard University Press, 1954 (Loeb Classical Library 403).

Aristotle, Poetics: edited and translated by Stephen Halliwell, Cambridge Massachusetts, Harvard University Press, 1995 (Loeb Classical Library 199).

Eliot, Thomas Stearns, Selected Prose: edited with an introduction by Frank Kermode, New York, Farrar, Straus and Giroux Publishers, 1975.

Goethe, Johann Wolfgang, Noten und Abhandlungen zum besseren Verständnis des West-östlichen Divans, Nordersteht, Hanse, 2016 (unveränderter Nachdruck der Originalausgabe aus dem Jahr 1887).

Gregorio di Nazianzo, Tutte le orazioni, a cura di Claudio Moreschini, traduzione italiana con testo a fronte e note di Chiara Sani e Maria Vincelli, Milano, Bompiani, 2000 (Bompiani il pensiero occidentale).

Il romanzo bizantino del XII secolo: Teodoro Prodromo - Niceta EugenianoEustazio Macrembolita - Constantino Manasse, a cura di Fabrizio Conca, Torino, Unione tipografico-editrice torinese, 1994 (Classici UTET).

Lucian, The Downward Journey or the Tyrant - Zeus Catechized - Zeus Rants (Iuppiter tragoedus) - The Dream or the Cock-Prometheus - Icaromenippus or the Sky-man - Timon or the Misanthrope - Charon or the Inspectors Philosophies for Sale. with an English translation by A. M. Harmon, Cambridge Massachusetts, Harvard University Press, 1915 (Loeb Classical Library 54), II.

Lucian, The Passing of Pperegrinus - The Runaways - Toxaris or Friendship - The Dance - Lexiphanes - The Eunuch - Astrology, The Mistaken Critic (Pseudologista) - The Parlament of the Gods - The Tyrannicide Disowned: with an English translation by A. M. Harmon, Cambridge Massachusetts, Harvard University Press, 1936 (Loeb Classical Library 302), V. 
Lucian, Anacharsis or Athletics - Menippus or the Descent into Hades On Funerals - A Professor of Public Speaking - Alexander the False Prophet - Essays in Portraiture - Essays in Portraiture Defended - The Goddesse of Surrye (De Syria dea): with an English translation by A. M. Harmon, Cambridge Massachusetts, Harvard University Press, 1925 (Loeb Classical Library 162), IV.

Lukian, Die Hauptwerke: Traum oder Lukians Lebensgang - Göttergespräche - Seegöttergespräche - Totengespräche - Ikaromenipp - Wahre Geschichten - Lügenfreund - Des Peregrinos Lebensende, herausgegeben und übersetzt von Karl Mras, München, Heimeran Verlag, 1980 (griechisch und deutsch - Sammlung Tusculum).

Platon, Symposion, übersetzt von Rudolf Rufener, mit einer Einführung, Erläuterungen und Literaturhinweisen von Thomas A. Szlezák, Düsseldorf und Zürich, Artemis und Winkler, 1992 (griechisch und deutsch - Sammlung Tusculum).

Platon, Werke in acht Bänden: Ion - Hippias II - Protagoras - Laches Charmides - Euthyphron - Lysis - Hippias I-Alcibiades I, herausgegeben von Günther Eigler, Darmstadt, Wissenschaftliche Buchgesellschaft, 2005 (= Platons Werke von Friedrich Schleiermacher, G. Reimer, Berlin $1828^{2}$ ).

Platone, Gorgia, introduzione, traduzione, note e apparati di Giovanni Reale, Milano, Bompiani, 2001 (Bompiani testi a fronte 36).

Platone, Fedro, intoduzione, traduzione, note e apparati di Giovanni Reale, Milano, Bompiani, 2000 (Bompiani testi a fronte 16).

Platone, La Repubblica: traduzione di F. Gabrieli, introduzione di Francesco Adorno, Milano, Biblioteca Universale Rizzoli, 1981 (testo greco a fronte).

Platone, Simposio, introduzione, traduzione, note e apparati di Giovanni Reale, Milano, Bompiani, 2000 (Bompiani testi a fronte 11).

\section{ЛЕКСИКА}

Bailly, Anatole, Dictionnaire grec-français, édition revue par L. Séchan et P. Chantraine, Paris, Hachette, 1950.

Beekes, Robert, Etymological Dictionary of Greek, Leiden, Brill, 2013 (Leiden Indo-European Etymological Dictionary Series volume 10).

Chantraine, Pierre, Dictionnaire etymologique de la langue grecque: Histoire des mots, Paris, Klincksieck, 1968 - 1980.

Deanović, Mirko - Jernej, Josip. Talijansko-hrvarski ili srpski rjenik / Vocabolario italiano-croato o serbo, Zagreb, Školska knjiga, $1973^{4}$.

Derksen, Rick, Etymological Dictionary of the Slavic Inherited Lexicon, Leiden, 2007 (Leiden Indo-European Etymological Dictionary Series, volume 4).

de Vaan, Michiel, Etymological Dictionary of Latin and the other Italic Languages, Leiden, Brill, 2008 (Leiden Indo-European Etymological Dictionary Series). 
Ранко Козић, Слика и мисао у језичком прастадијуму и њихов значај за студије ...

Frisk, Hjalmar, Griechisches etymologisches Wörterbuch, Heidelberg, Carl Winter Universitätsverlag, 1954-1972.

Jakić, Blanka - Hurm, Josip, Hrvatsko ili srpsko-njemački rječnik/Kroatisch oder serbisch-deutsches Wörterbuch, Zagreb, Školska knjiga, $1987^{5}$.

Klajn, Ivan, Italijansko-srpski rečnik, Beograd, Nolit, 1996.

Köbler, Gerhard, Indogermanisch-neuhochdeutsches und neuhochdeutsch-indogermanisches Wörterbuch, Gießen, 1982 (Arbeiten zur Rechts- und Sprachwissenschaft, Band 13).

Konersmann, Ralf (ed.), Wörterbuch der philosophischen Metaphern, Darmstadt, Wissenschaftliche Buchgesellschaft, $2011^{3}$.

Liddell, Henry George - Scott, Robert - Jones, Henry Stuart, A Greek-English Lexicon, Oxford, Clarendon Press, 1843.

Montanari, Franco, Vocabolario della lingua greca, Torino, Loescher, $2013^{3}$.

Passow, Franz, Handwörterbuch der griechischen Sprache, Leipzig, F. C. W. Vogel, 1841.

Pianigiani, Ottorino, Vocabolario etimologico della lingua italiana, Albrighi, Società editrice Dante Alighieri, 1907.

Pokorny, Julius, Indogermanisches etymologisches Wörterbuch, Tübingen, Bern, München, Francke Verlag, 1957-1969.

Skok, Petar, Etimologijski rječnik hrvatskoga ili srpskoga jezika, Zagreb, Jugoslavenska akademija znanosti i umjetnosti, 1972.

Vasmer, Max, Russisches etymologisches Wörterbuch, Heidelberg, Carl Winter Universitätsverlag, 1955.

Walde, Alois, Lateinisches etymologisches Wörtrebuch, Heidelberg, Carl Winter Universitätsverlag, 1910.

Ranko Kozić

\author{
IMAGE AND THOUGHT IN THE PRIMORDIAL PERIOD \\ OF LANGUAGE AND THEIR IMPORTANCE FOR THE STUDIES \\ OF PHILOLOGY, LITERATURE AND PHILOSOPHY \\ (Summary)
}

Creativity of the language, as expressed in its deepest strata, is the main topic of this paper. The mentioned creativity found its reflection in an exemplary way in the images and metaphors exuding all the vigour, charm and freshness in which a primordial sensibility of language tried to clothe its relation to the surrounding world. The greatest temptation and at the same time the greatest pleasure for the researcher consists in his striving to establish logical relations between images, metaphors and tropes coming to light in these early stages of prehistory and being themselves a necessary prerequisite for the acquisition of logic of language otherwise not to be fully gained by applying long-established methods in the study of the language as a subject-matter of scientific research. In this study the effort has also been made to point out the fact that the effectiveness in the study of humanities can consider- 
ably be enhanced by acquiring the basic knowlege of the logical relations referred to above. The most important conclusion that could be drawn from this drive into the semantic spectrum of the word root amounts to the fact that the bold metaphors sprung from the mentioned root show us in a roundabout way how the sublime creation in fields of literature and philosophy can be achieved, as testified by the parallelisms existing between the images spontaneously created by the word root itself and those literary and philosopical ones artificially made, which, taken together, points to the necessity of carrying out an all-encompassing research work on the metaphors appearing in the European literature.

Keywords: semantics of the word roots, hermeneutics, language teaching strategy, literature and philosophy in educational system, indoeuropean philology; logic of language; theory of translation.

Примљено 8. јуна 2021, прихваћено за објављивање 29. јуна 2021. године. 